\title{
Volatile fatty acids concentration and efficiency of microbial protein synthesis of concentrate cassava peel diet with different levels of protein sources
}

\author{
Arya Dwi Saputra ${ }^{\text {, Kusmartono Kusmartono }}{ }^{2 *}$, Mashudi Mashudi ${ }^{2}$, and Poespitasari \\ Hazanah Ndaru $^{2}$ \\ ${ }^{1}$ Postgraduade Programe, Faculty of Animal Science, Universitas Brawijaya, Malang 65145, \\ Indonesia \\ ${ }^{2}$ Faculty of Animal Science, Brawijaya University, Malang 65145, Indonesia
}

\begin{abstract}
This study was conducted to evaluate the effects of different levels of protein sources in a concentrate cassava peel diet on volatile fatty acid (VFA) concentration and efficiency of microbial protein synthesis (EMPS) by in vitro method. The five diet treatments in this study consisted of cassava meal (CM), cassava peel (CP), cassava leaves (CL) and moringa leaves (ML) with the proportion applied were $\mathrm{T} 1=\mathrm{CM} 70 \%+\mathrm{CP} 20 \%+$ CL5\% + ML5\%; T2 $=\mathrm{CM} 60 \%+\mathrm{CP} 20 \%+\mathrm{CL} 10 \%+\mathrm{ML} 10 \% ; \mathrm{T} 3=\mathrm{CM} 50 \%$ $+\mathrm{CP} 20 \%+\mathrm{CL} 15 \%+\mathrm{ML} 15 \% ; \mathrm{T} 4=\mathrm{CM} 40 \%+\mathrm{CP} 20 \%+\mathrm{CL} 20 \%+$ ML20\%; T5=CM30\% + CP20\% + CL25\% + ML25\%. The experiment used a randomized block design with five treatments and three replications. The results showed that increasing the level of protein sources in the ration tended to increase the value of total VFA, acetate, propionate, $\mathrm{CO}_{2}$, and $\mathrm{CH}_{4}$ in which T3 had the highest values. However, the effect of treatments were significant in EMPS value $(\mathrm{P}<0.01)$. It was concluded that increasing levels of cassava and moringa leaves in the concentrate cassava peel diet tended to increase the value of total VFA, acetate, propionate, butyrate, $\mathrm{CO}_{2}$, and $\mathrm{CH}_{4}$ which led to a significant increase in EMPS values.
\end{abstract}

\section{Introduction}

Carbohydrates are fermented by rumen microbes to produce volatile fatty acids (VFA) which consist of $60-70 \%$ acetic acid, $15-20 \%$ propionic acid, and $10-15 \%$ butyric acid [1]. The concentration of VFA is influenced by the level of feed ingredient fermentability in the rumen [2]. Apart from their function as a source of energy for the host, VFAs also serve as a source of carbon skeletons as well as ATP for microbial protein synthesis [3]. The microbial protein produced in the rumen and flows into the abomasum provides the majority of protein for further digestion by $\mathrm{HCl}$-pepsin and trypsin to form amino acids in the small intestine for absorption (50-80\%). Bach et al. [4] concluded that rumen ammonia is the main precursor,

*Corresponding author: kusmartono_ansi@ub.ac.id 
and its efficiency of conversion into microbial protein is determined by the type and amount of feed consumed by ruminants. Ramaiyulis et al. [5] stated that rumen microbial growth, largely determined by the availability of essential nutrients such as soluble carbohydrates and protein.

Cassava (Manihot utilissima Crantz) is a major plant in Indoneisa with 19.3 million tons production in 2018 [6]. This perennial plant contains high energy in the root [7] and a high protein in the leaves [8]. Cassava meal which formed from the drying and grinding process of cassava tubers contains $87.3 \%$ dry matter (DM), $2.13 \%$ crude protein $(\mathrm{CP})$, and $3.2 \%$ crude fiber (CF) [9]. Lukuyu et al. [10] mentioned that cassava meal provides $96.2 \%$ organic matter (OM) and non-fiber carbohydrates (NFC) 82\%. Cassava peels contained 7.1\% OM, 7.1\% CP, $2 \%$ extract ether (EE), and 66.4\% NFC. Hang et al. [11] mentioned that cassava leaves are rich in protein with $29.4 \% \mathrm{DM}$ and $22.1 \% \mathrm{CP}$.

Retnaningrum et al. [12] reported that the use of cassava meal as an energy source to supplement maize stover basal diet had the highest digestibility and daily weight gain of crossbred Limousine. [13] mentioned that cassava peel can replace corn as an energy source in ration rated from ruminal parameters on small ruminants. Mulyati et al. [14] stated that cassava and moringa leaves potentially as a supplement on low-quality roughages to support rumen microbial growth and activity due to high protein content. This study aimed to evaluate the effects of different levels of protein sources in a concentrate cassava peel diet on VFA concentration and efficiency of microbial protein synthesis (EMPS) by in vitro method.

\section{Materials and methods}

\subsection{Location and time}

This research was conducted in the Nutrition and Animal Feed Laboratory Faculty of Animal Science Brawijaya University in November.

\subsection{Materials}

Materials used were set of tools for volatile fatty acids (VFA) and efficiency of microbial protein synthesis (EMPS) analysis and feedstuffs consisted of cassava meal (CM), cassava peel (CP), cassava leaves (CL) obtained from Ngajum, Malang, and moringa leaves (ML) took from Kambingan Village, Tumpang, Malang.

\subsection{Method}

This study used a Randomized Block Design (RBD) with five treatments and three replication. The treatments applied were T1=CM70\% + CP20\%+CL5\% + ML5\%; $\mathrm{T} 2=\mathrm{CM} 60 \%+\mathrm{CP} 20 \%+\mathrm{CL} 10 \%+\mathrm{ML} 10 \%$; T3 $=\mathrm{CM} 50 \%+\mathrm{CP} 20 \%+\mathrm{CL} 15 \%+\mathrm{ML} 15 \%$; $\mathrm{T} 4=\mathrm{CM} 40 \%+\mathrm{CP} 20 \%+\mathrm{CL} 20 \%+\mathrm{ML} 20 \%$; T $5=\mathrm{CM} 30 \%+\mathrm{CP} 20 \%+\mathrm{CL} 25 \%+\mathrm{ML} 25 \%$. Table 1 showed the chemical composition of feedstuffs and treatments.

The in vitro method used Makkar et al. [15] protocol, in which after the incubation, the residue were centrifuged to separate sediment and supernatant parts. The separated sediment was dried and weighed for measuring fermented organic matter (FOM) value. The separated supernatant was used to determine the VFA total, acetate $\left(\mathrm{C}_{2}\right)$, propionate $\left(\mathrm{C}_{3}\right)$, and butyrate $\left(\mathrm{C}_{4}\right)$ by gas chromatographic techniques. The result of VFA concentration also used to determine $\mathrm{CO}_{2}$ and $\mathrm{CH}_{4}$ by Van Soest [16] equation. For determining of EMPS value, the residues were refluxed using NDS solution and calculated with Bach et al.[4] equation. 
Table 1. Chemical composition of feedstuffs and treatments

\begin{tabular}{|c|c|c|c|c|c|c|c|c|}
\hline \multirow{2}{*}{ Feed } & \multicolumn{7}{|c|}{ Chemical Composition (\%) } \\
\cline { 2 - 9 } & DM & Ash* & CP* & EE* & CF* & NFE* & ADF* & NDF* \\
\hline Cassava Meal (CM) & 84.41 & 2.63 & 2.86 & 0.84 & 2.90 & 90.77 & 2.18 & 8.96 \\
\hline Cassava Peel (CP) & 24.32 & 7.51 & 9.18 & 1.72 & 9.88 & 71.72 & 9.36 & 28.36 \\
\hline Cassava Leaves (CL) & 25.73 & 9.87 & 25.48 & 9.72 & 18.46 & 36.47 & 47.15 & 46.50 \\
\hline Moringa Leaves (ML) & 24.23 & 12.97 & 27.38 & 6.78 & 10.35 & 42.51 & 13.39 & 17.51 \\
\hline T1 & 90.62 & 4.26 & 9.10 & 1.22 & 4.76 & 80.66 & 7.34 & 16.03 \\
\hline T2 & 91.47 & 5.03 & 11.50 & 1.69 & 5.66 & 76.12 & 8.50 & 17.50 \\
\hline T3 & 91.87 & 5.98 & 12.56 & 2.35 & 6.82 & 72.29 & 10.19 & 19.03 \\
\hline T4 & 92.29 & 6.94 & 14.46 & 3.16 & 7.56 & 67.88 & 11.68 & 22.57 \\
\hline T5 & 90.88 & 7.87 & 19.28 & 4.65 & 8.57 & 59.62 & 13.09 & 33.14 \\
\hline
\end{tabular}

*) Based on $100 \%$ of DM [17]

\subsection{Statistical analysis}

The data obtained were analyzed by analysis of variance (ANOVA) and followed by Duncan's Multiple Range Test if the treatments gave a significant effect on the variables measured according to Sudarwati et al. [18].

\section{Results and discussion}

Table 2 presents the result of VFA total, acetate, propionate, butyrate, $\mathrm{CO}_{2}, \mathrm{CH}_{4}$, and EMPS by treatments. The results showed the treatment did not significantly affect the value of all parameters $(\mathrm{P}>0.05)$, except EMPS which showed a significant by treatments $(\mathrm{P}<0.01)$. Treatment T3 achieved the highest value of total VFA (148.6 mMol/1), whilst the lowest total VFA value was recorded in T1 $(97.4 \mathrm{mMol} / \mathrm{l})$. Similar trends were observed in acetate, propionate, butyrate, $\mathrm{CO}_{2}$, and $\mathrm{CH}_{4}$ values. Increased proportions of cassava and moringa leaves in the ration has led to EMPS value being highest for treatment T5 $(27.28 \mathrm{~g} \mathrm{~N} / \mathrm{kg}$ FOM), whilst T2 had the lowest value of EMPS (12.10 g N/kg FOM). This evidence indicates the potential of cassava and moringa leaves as protein sources to supplement cassava peel and cassava meal as carbohydrate sources.

The VFA total in this study was high because the concentration of VFA was generally from $70-150 \mathrm{mMol}$ [19] and this may be due to a high fermentation rate of cassava meal and peels in the rumen. The high starch diet in ration increases acetate and propionate value [20] and increases the amylolytic microbial population [19]. Suharlina et al. and Gumilar et al. $[21,22]$ stated that fibrous feed becomes acetic in the rumen which probably caused acetate and propionate to be higher. In contrast, T3 has a higher concentration of VFA than T4 and T5 which have higher fiber. It also means that the high protein content in the ration without being followed by an adequate energy source cannot be utilized properly by microbes. Retnaningrum et al. [12] reported that the VFA increased with the addition of cassava meal in the ration, but at the $70 \%$ proportion of cassava meal, drastically decreased total VFA, 
acetate, propionate, and butyrate due to inadequate proportion of protein source. Santos et al. [13] reported that cassava peel tended to decrease propionate and increase the acetate concentration in replacement of corn.

Tabel 2. Total VFA, acetate, propionate, butyrate, $\mathrm{CO}_{2}, \mathrm{CH}_{4}$ and EMPS of treatments

\begin{tabular}{|c|c|c|c|c|c|c|}
\hline \multirow{2}{*}{ Parameters } & \multicolumn{5}{|c|}{ Treatments } & \multirow{2}{*}{ SEM } \\
\cline { 2 - 6 } & T1 & T2 & T3 & T4 & T5 & \\
\hline Total VFA (mMol/l) & 97.40 & 133.10 & 148.63 & 136.13 & 137.60 & 8.298 \\
\hline Acetate $(\mathrm{mMol} / \mathrm{l})$ & 61.67 & 86.43 & 95.63 & 87.40 & 85.30 & 5.538 \\
\hline Propionate $(\mathrm{mMol} / \mathrm{l})$ & 21.63 & 28.0 & 30.53 & 29.90 & 30.67 & 2.074 \\
\hline Butyrate $(\mathrm{mMol} / \mathrm{l})$ & 14.10 & 18.67 & 22.47 & 18.83 & 21.63 & 1.516 \\
\hline $\mathrm{CO}_{2}(\mathrm{Mol})$ & 58.86 & 58.82 & 60.21 & 57.90 & 60.0 & 0.688 \\
\hline $\mathrm{CH}_{4}(\mathrm{Mol})$ & 32.63 & 34.19 & 34.77 & 33.74 & 33.25 & 0.841 \\
\hline EMPS* $(\mathrm{g} \mathrm{N} / \mathrm{kg} \mathrm{FOM})$ & $12.71^{\mathrm{a}}$ & $12.10^{\mathrm{a}}$ & $17.37^{\mathrm{ab}}$ & $20.11^{\mathrm{ab}}$ & $27.28^{\mathrm{b}}$ & 1.910 \\
\hline
\end{tabular}

Different superscript in the same row showed the significant effect at $\mathrm{P}<0.01\left(^{*}\right)$

EMPS= Efficiency of Microbial Protein Synthesis

FOM= Fermented Organic Matter

Apart from VFA levels, $\mathrm{CH}_{4}$ can be assessed for feed efficiency parameters. In this study, the CH4 trend was similar to the VFA value which the highest value was T3 $(34.77 \mathrm{Mol})$ and the lowest in T1 $(32.63 \mathrm{Mol})$. McDonald et al. [1] mentioned that the organic matter degradation by rumen microbes will produce VFA, $\mathrm{CO}_{2}, \mathrm{CH}_{4}$, and other gasses. The higher VFA formed higher the gasses produced. Muchlas et al. [23] stated that the higher $\mathrm{CH}_{4}$ production illustrates more energy wasted, which indicates the more inefficient the feed was.

Karsi and Russel [24] mentioned that EMPS values generally range from 10-70 g N/kg FOM and the optimal value for EMPS above $30-40 \mathrm{~g} \mathrm{~N} / \mathrm{kg}$ FOM, thus the EMPS value in this study is low. It may be caused by the low fiber diet and a high concentrate that caused the low rumen $\mathrm{pH}$ as stated by Muchlas et al. [23]. The low EMPS in this study may be causing a high value of $\mathrm{NH}_{3}$, in which according to Bach et al. [4], the available energy and amino acid (AA) will be used directly for microbial protein synthesis, while limited energy will cause amino acid (AA) to be deaminated and the carbon skeleton fermented into VFA. The excess of AA will be removed from the cytoplasm into ammonia because some rumen microbes lack of mechanism for emitting AA.

\section{Conclusion}

In conclusion, increasing levels of cassava and moringa leaves in the concentrate cassava peel diet tended to increase the value of total VFA, acetate, propionate, butyrate, $\mathrm{CO}_{2}$, and $\mathrm{CH}_{4}$ which led to a significant increase on EMPS values.

The authors wish to thank Rector of Brawijaya University for financial support through Professor research grant. 


\section{References}

1. P. Mc Donald, R.A. Edwards, J.F.D. Greenhalgh. C.A. Morgan, L.A. Sinclair, and R.G. Wilkinson, Animal Nutrition $7^{\text {th }}$ Edition (Benjamin Cummings, 2011)

2. C.J.B. Sendow, C.T. Noviandi, and R. Utomo, Buletin Anim. Sci. 41 (2017)

3. E.R. Orskov, Protein Nutrition in Ruminants, 2nd Edition (Academic Press, 1992)

4. A. Bach, S. Calsamiglia, and M.D. Stern, J. Dairy Sci. 88, 9-21 (2005)

5. Ramaiyulis, R.W.S. Ningrat, M. Zain, and L. Warly, Pak. J. Nutr. 18 (2019)

6. A. Amir, B.P. Purwanto, Nahrowi, A. Atabany, Salundik, and A. Yani, LRRD 33 (2021)

7. P. Sumadong, A. Cherdtong, S. So, and M. Wanapat, BMC. Vet. Res. 17 (2021)

8. S. Suharti, H. Oktafiani, A. Sudarman, M. Baik, and K. G. Wiryawan, AOAS. 66 (2021)

9. S. Retnaningrum, Kusmartono, Mashudi, K.J. Harper, and D. Poppi, IOP Conf. Ser. Earth Environ. Sci. 478 (2020)

10. B. Lukuyu, I. Okike, A. Duncan, M. Beveridge, and M. Blummel, Use of Cassava in Livestock and Aquaculture Feeding Programs (ILRI Editorial and Publishing Services, Addis Ababa, Ethiopia, 2014)

11. L.T.T. Hang, T.R. Preston, N. Xuan Ba, and D. Van Dung, LRRD. 31 (2019)

12. S. Retnaningrum, Kusmartono, Mashudi, K.J. Harper, and D.P. Poppi, Animal, 15, 1-7 (2021)

13. V.L.F. Santos, M.A. Ferreira, M.C.B. Siqueira, T.T.B. Melo, J.L. Silva, I.B. Andrade, A.A. Soares, and C.T.F. Costa, Small Rumin. Res. 113, 88-92 (2015)

14. Mulyati, Kusmartono, Hartutik, and Rusdi, LRRD, 27 (2015)

15. H.P.S. Makkar, M. Blümmel, and K. Becker, British J. Nutri. 73, 897-913 (1995)

16. J. P. Van Soest, Nutrition Ecology of Ruminant, 2nd Edition (Cornell University Press, Ithaca, 1994)

17. A.D. Saputra, Kusmartono, Mashudi, P.H. Ndaru, IOP Conf. Ser. Earth Environ. Sci. 888 (2021)

18. H. Sudarwati, M.H. Natsir, and V.M.A. Nurgiartiningsih, Statistika dan Rancangan Percobaan dalam Bidang Peternakan (Universitas Brawijaya Press, Malang, Indonesia, 2019)

19. A.D. Putridinanti, C.T. Noviandi, Gunawan, A. Agus, K. Harper, and D. Poppi, IOP Conf. Ser. Earth Environ. Sci. 387 (2019)

20. B. Hatew, S.C. Podesta, H. Van Laar, W. F. Pellikaan, J.L. Ellis, J. Dijkstra, and A. Bannink, J. Dairy. Sci., 98, 486-499 (2015)

21. Suharlina, D.A. Astuti, Nahrowi, A. Jayanegara, and L. Abdullah, JITAA, 41 (2016)

22. D.A.K.W. Gumilar, E. Rianto, and M. Arifin, IOP Conf. Ser. Earth Environ. Sci. 119 (2018)

23. M. Muchlas, Kusmartono, and Marjuki, Jurnal Ilmu-Ilmu Peternakan, 24, 8-19 (2014)

24. M.A. Karsli and J.R. Russel, J. Vet. Anim. Sci. 25, 681-686 (2001)

25. J. Achmadi, E. Pangestu, Surahmanto, A. Subrata, and M. A. Harahap, IOP Conf. Ser. Earth Environ. Sci. 518 (2020) 